\author{
Md. Farhadur Rahman, Kamrul Islam*, \\ Kazi Nazrul Islam \\ Institute of Forestry and Environmental Sciences, University \\ of Chittagong, Bangladesh \\ Dates: Received: 26 March, 2016; Accepted: 04 \\ April, 2016; Published: 07 April, 2016 \\ *Corresponding author: Kamrul Islam, Institute of \\ Forestry and Environmental Sciences, University of \\ Chittagong, Bangladesh, Tel: +08801672484174; \\ E-mail: ksujonifescu@gmail.com \\ www.peertechz.com \\ ISSN: $2455-488 X$
}

Keywords: Industrial symbiosis; Industrial ecology; Industrial policy; Industrial management

\author{
Review Article
}

\section{Industrial Symbiosis: A Review on Uncovering Approaches, Opportunities, Barriers and Policies}

\section{Introduction}

With the emergence of human civilization, human started to extract and use resources from nature for subsistence and economic development. Unlimited resources gave us the opportunity to generate unlimited waste. Resource was not a matter of concern at that time as population compared to resource was insignificant. Unlimited extraction proportionately decreases the availability of resources thus generated unlimited waste, later on which became a great concern for us. Different strategies were taken to back the waste into production system. This thinking gave birth to an idea where different farms and entities collaborate together to enhance sustainable utilization of resource system commonly termed as industrial ecology.

The history of industrial symbiosis [1], is more than 150 years old. With the passage of time different economists, geographers and sociologists gave their views related to this topic. Previously common thought was that industries go oppose to the environment. Their opinions and case studies helped to establish a linkage between industries and environment to attain sustainability as the resources are limited. Granovetter [2], identified that cluster of firms in a territory achieved more success than others if they can develop untraded interdependencies such as flows of knowledge, customs or understandings and trust. Desrochers \& Leppälä [3], discussed successive historical progression of industrial symbiosis. In his article, he compared past day's and present day's synergies. On the other hand, Chertow [4] showed how industrial symbiosis got international acceptance over time.
According to Frosch \& Gallopoulos [5], industrial ecosystem is a system where consumption of energy and materials is optimized, waste generation is minimized and the effluents of one process serve as the raw material for another process. It also functions as an analogue of biological ecosystems [5]. In the same year (1989), some inter related firms started to share their resources in Kalundborg, Denmark which set a mile stone in the field of industrial ecology and justified the theory of Frosch \& Gallopoulos [5]. This new idea got recognition as "The industrial symbiosis at Kalundborg". 1989 is considered as an inspirational year for industry and environment by Chertow [6]. In that year a fundamental article was also published by Scientific American named "Strategies for manufacturing" by Frosch and Gallopoulos. The core of the article gave illustration of approaches, policies and ideal condition of sustainable industrial ecosystem. In that article Frosch and Gallopoulos deciphered that an ideal industrial ecosystem may never be attained in practice, but both manufacturers and consumers must change their habits to approach it more closely if the industrialized world is to maintain its standard of living and the developing nations are to raise theirs to a similar level without adversely affecting the environment. They also denoted that the consumption of energy and materials is optimized and effluent of one process ....serve as the raw material for another process [5]. Industrial ecology creates a sense what we should do and industrial symbiosis shows us a prospect what we can do in future. Symbiosis came from a Greek word "syn" means together and "biosis" means living, thus symbiosis means short term or long term relationship between two individuals. Industrial symbiosis is a concept used to describe geographically proximate inter-firm 
relationships involving the exchange of residual materials, water and energy. Most accepted definition of IS was given by Chertow [4], industrial symbiosis, as part of the emerging field of industrial ecology, demands resolute attention to the flow of materials and energy through local and regional economies. Industrial symbiosis engages traditionally separate industries in a collective approach to gain competitive advantage involving physical exchange of materials, energy, water, and/or by-products. The keys to industrial symbiosis are collaboration and the synergistic possibilities offered by geographic proximity. But Lombardi \& Laybourn [7] provided redefined definition which included emerging components of IS projects. According to them - IS engages diverse organizations in a network to foster eco-innovation and long-term cultural change. Creating and sharing knowledge through the network yields mutually profitable transactions for novel sourcing of required inputs, valueadded destinations for non-product outputs, and improved business and technical processes.

However, after emergence of Kalundborg, several industrial synergies have been discovered and initiated in 27 countries. More than 300 European and non-European eco -industrial parks [8] have already showed greater prospects. These industrial clusters will very likely to form a symbiotic network if they are provided with three primary privileges: (1) by product reuse, (2) utility or infrastructure sharing, and (3) joint provision of services [6]. Twenty five years have been passed and researchers identified key problems and provided their time dependent and area specific resolutions [9-11]. Another important component is policy instruments which have an opposite two fold effect, sometimes it helps in symbiosis formation or imposes restriction on industrial owners and sometimes policy fragmentation hinders potential projects and made it unsuccessful. So, approaches, opportunities, and barriers and policy instruments can be taken as three important attributes of industrial symbiosis. Many review articles and full length research papers have already been published but there is still data deficit about the aforementioned components and more importantly none tried to review these three component altogether at uncovering stage. In this paper the authors put their concentration on the different approaches that enhance industrial symbiotic relations, opportunities, barriers and policies instruments irrespective of any symbiosis project.

So, the focus of the review is threefold, namely:

- To identify approaches taken to initiate to maintain industrial symbiotic projects.

- To review opportunities those have been identified by different researchers.

- To identify key policy instruments those enhance symbiotic relation between firms and industries.

\section{Approches and enabling factors}

During 1800s, when industrialization had just started, the relation between natural resources and production system was linear. As the resources were limited to exploit, a non-linear relationship evolved in production system (waste as raw material). Industrial symbiosis gives material and energy efficiency along with better environmental sustainability.

Literature review gives us two distinct processes for arising industrial symbiosis initiatives- (i) self-organization process and (ii) third party planning or engineered process [6]. Organizational theory draws a distinction a between 'serendipitous' and 'goal-

Table 1: Difference between interventions in planned and spontaneous approach

\begin{tabular}{|c|c|c|}
\hline Agents & Planned approach & Spontaneous approach \\
\hline Government & $\begin{array}{l}\text { planning ordinance for eco- industrial developments, } \\
\text { involving the design, development and management of } \\
\text { the site } \\
\text { economic incentives: tax cuts for adhering companies, } \\
\text { funding brown field/green field development, funding } \\
\text { design teams }\end{array}$ & $\begin{array}{l}\text { - environmental regulation: water, air and waste (target/ } \\
\text { limits requirements:- management process }\end{array}$ \\
\hline Govt. institutions & $\begin{array}{l}\text { - } \quad \text { economic incentive: financing and/or subsidies } \\
\text { - } \quad \text { material flow analysis/by-product or waste matching } \\
\text { - informational and decision tools developers } \\
\text { - intermediary to establish synergy }\end{array}$ & - emission of permits \\
\hline $\begin{array}{l}\text { Private associations (e.g. } \\
\text { industry, business) }\end{array}$ & - intermediary to find "fitting" companies & $\begin{array}{l}\text { - } \quad \text { network development and promotion } \\
\text { - } \quad \text { information exchange platform } \\
\text { - } \quad \text { mediation role } \\
\text { monitoring }\end{array}$ \\
\hline Universities & $\begin{array}{l}\text { - } \quad \text { part of design teams } \\
\text { - } \quad \text { material flow analysis/ by-product or waste } \\
\end{array}$ & $\begin{array}{l}\text { - } \quad \text { uncovering of linkages } \\
\text { - } \quad \text { economic / environmental analysis of linkages } \\
\text { report of synergies }\end{array}$ \\
\hline Business & $\begin{array}{l}\text { - } \quad \text { anchors at the development site } \\
\text { - } \quad \text { high rated flows of waste type materials and /or residual } \\
\text { - utilities; complementarities in material flows- } \\
\text { engines for jobs and attracting more businesses }\end{array}$ & $\begin{array}{l}\text { - } \quad \text { identification of business opportunities in resource } \\
\text { - } \quad \text { econanament } \\
\text { - } \quad \text { funding of uncovering/ discover opportunities- } \\
\text { - } \quad \text { network promotion regional networks / clusters } \\
\text { - } \\
\text { - } \\
\text { green for reuse/ recycling technologies }\end{array}$ \\
\hline
\end{tabular}


directed' network processes. Serendipitous processes occur through the "happenstance of people meeting and liking one another," while goal-directed processes occur when "parties interact to achieve, plan, coordinate, or decide on their individual and collective activities. They showed how two different processes influence initialization and combined influence on IS resilience [12]. But Costa \& Ferrão [13], deciphered a clear distinction between planned approach and spontaneous approach. They documented how different agents behave differently if they (agents) approached towards planned or spontaneous way. Interventions in planned and spontaneous approaches adapted from Costa \& Ferrão [13], are given in Table 1.

From the planned and spontaneous approaches of industrial symbiosis, it is clear that the different entities (e.g. government, government institutions, business etc.) have some key roles to accomplish for achieving certain goals (i.e. reducing cost and getting higher benefits considering the environmental improvement). Government together with its institutions can play lead role by adopting some programs like reducing taxes or providing economic incentives for companies who adopt symbiosis in their production systems. Research organizations can help the organizations that adopt IS concept by providing the design, information on resources to take better decision. After setting up IS in industry/organization, they should develop their own capacity. In our view, the parties adopting IS may establish a certain department which will be responsible for updating inventories of water use, energy use, waste generation etc. This may increase initial production cost, but in the long run it will enhance the performance as the parties don't need seeking for help from other external organizations. As we know that industrial symbiosis is the synergies of collocated of industries; regional resource synergies improve flow and exchange of natural resources to achieve more productive use of material, energy or water. Bossilkov et al. [10], distinguished three types of regional synergies- resource exchange: what resource is being exchanged between companies; processing involved: the degree to which the "wasted" resource is being processed before it can be utilized by the other company (ies) involved in the synergy project; synergies: the business relation governing the synergy project (Table 2).

Efficient use of resources are the central concept in symbiotic network of industries. Water, energy are the two key and most important resources and almost every single industry is dependent on it. Reuse of water is a better option as it would also decrease cost of energy use along with saving water for further use. Used water can be used largely for cooling purposes inside industries. Bilateral resource sharing can be of great importance as it would increase performance of the industries where both of the industries are in win-win situation and environmental aspects in also ensured. Before disposal of waste, useable items should be segregated from the non-useable. Again the non-usable items for one production system may be required by others. This process will diminish the larger volume of waste to a smaller one and industries will be benefitted economically also.

Similar type of synergies were critically studied by Chertow [4], she studied 18 eco - industrial parks and categorized them into five groups according to their material exchange and driving factors that enhance their formation and continuation. These discussed categories were mention as IS types by author herself. The types are as following-Type 1: through waste exchanges; Type 2: within a facility, firm, or organization; Type 3: among firms collocated in a defined eco-industrial park; Type 4: among local firms that are not collocated and Type 5: among firms organized "virtually" across a broader region. These are some ways how the industries can make a cluster. There are some factors that also help in formation of industrial cluster. According to Teh et al. [14], the determinant factors of industrial symbiosis are- (i) institution, (ii) law and regulation, (iii) finance, (iv) awareness and capacity building, (v) technology, (vi) research and development,(vii) information, (viii) collaboration, (ix) market, (x) geography proximity, (xi) environment issues and, (xii) industry structure. Apart from determinants, Boons et al. [15], mentioned 5 factors for industrial symbiosis. The factors were-(1) the need for a learning process and strategic vision, (2) issues related to the diversity of involved actors and its consequences for connectance and interdependency, (3) the requirement of trust and ways to foster it, (4) the presence of anchor tenants or coordinating bodies and the roles they can play in providing information, education and as a platform for communication, and (5) the presence of an enabling context, which may defined in terms of policies, regulations and other institutions but also in much broader terms such as cultural, structural, spatial and temporal embededness. In their article, they also deciphered role of institutional capacity for establishing IS and also distinguished 3 dimensions of institutional capacity as relational capacity, knowledge capacity and mobilization capacity. Van

Table 2: Different types of regional synergies among industries.

\section{Type of resource exchange}

Water: exchange and reuse of cooling water and process water, any collective treatment and recycling of wastewater

Energy: shared use of energy infrastructure, cogeneration and/or recovery of waste heat from steam and electricity generation.

Non-process waste: may include waste generated while carrying out routine or emergency maintenance, packaging materials, machinery components, general household waste, landscape waste, construction or demolition debris.

Other: this type of exchange generally features some sort of service or utility sharing

Source: Bossilkov et al. [10].
Type of processing

Direct use or reuse: without any further processing except for transport and storage.

Energy recovery or alternative fuels: covers waste heat recovery and alternative fuels for boilers and kilns. Shared electricity and gas utilities and co-generation facilities also fall Service: interaction between into this category.

Material recovery: involves separation and recovery processes to reclaim specific materials found in the byproduct/waste stream for the beneficial use. Conversion into a useful product: processing to produce a different useful product.

Environmentally sound disposal: collective treatment of wastewater to enable its safe disposal.
Type of synergy:

Bilateral: interaction between two parties, either one-way or two-way exchange.

one company on one end and two or more on the other end of the synergy. Network: - multilateral interaction between more than two parties in both directions 
Berkel [16], a prominent industrial ecologist, found three enabling mechanisms- (1) facilitating structures that encourage collaboration among industries in the same industrial area, (2) operational and contractual arrangements that enable of the necessary resources for implement of IS project and (3) evaluation method that can track and quantify the environmental, social, and economic benefits of IS projects. Another industrial ecologist, Aparisi [11], complied key factors for the emergence of IS and those are given in Table 3.

In most of the cases there is hardly any pollution control framework adopted by developing nations of the world. Absence of this is one of the key obstacles in adopting industrial symbiosis. Proper

Table 3: Key factors for the emergence of IS.

\begin{tabular}{|l|l|}
\hline $\begin{array}{l}\text { Complementary } \\
\text { activities }\end{array}$ & $\begin{array}{l}\text { Industrial activities need to be complementary in their } \\
\text { needs of resources }\end{array}$ \\
\hline $\begin{array}{l}\text { Suitable } \\
\text { regulatory } \\
\text { framework }\end{array}$ & $\begin{array}{l}\text { A suitable pollution control regulatory framework may } \\
\text { create the incentives for } \\
\text { by-product exchanges }\end{array}$ \\
\hline Trust & $\begin{array}{l}\text { Trust among the involved partners reduces transaction } \\
\text { costs, risk and uncertainty of IS exchanges and is key in } \\
\text { the creation of collaborative structures }\end{array}$ \\
\hline Reciprocity & $\begin{array}{l}\text { Togeth er with trust, reciprocity assures that cooperation is } \\
\text { mutually beneficial for all the actors involved }\end{array}$ \\
\hline $\begin{array}{l}\text { Short mental } \\
\text { distance }\end{array}$ & $\begin{array}{l}\text { Short mental distance assures convergence of goals and } \\
\text { visions and facilitates communication. }\end{array}$ \\
\hline $\begin{array}{l}\text { Self-organization/ } \\
\text { bottom-up } \\
\text { approach }\end{array}$ & $\begin{array}{l}\text { The involvement of key stakeholders, and especially } \\
\text { industries, in the process is } \\
\text { essential for its further development }\end{array}$ \\
\hline \multicolumn{2}{|l|}{$\begin{array}{l}\text { Transportation costs and other transaction costs are } \\
\text { significantly reduced when companies are located in close } \\
\text { geographical proximity. Distance may have a discouraging } \\
\text { effect on the establishment of collaborative linkages. }\end{array}$} \\
\hline Source: Aparisi, (2010) [11].
\end{tabular}

pollution control guidelines would ensure by-product exchange among the participating industries and create economic incentives as well. If the industries are co-located then the transportation costs will be relatively very low which will ultimately encourage exchange of products and vice versa. Long term improvement of the symbiotic network will not be achieved if there is absence of trust among the participating partner organizations. It should be ensured considering the long term development aspects.

Chertow briefly described several elements and analytical tools for industrial symbiosis. She mentioned embedded energy and materials as one of the tools of IS project. In production system, a product requires energy and material which are embedded in that product. By reusing by-products, industrial symbiosis preserves the embedded materials and energy for a longer period within the industrial system. (e. g. by reusing steam or waste heat to produce electricity) Life cycle perspective that is another significant tool of IS project that also need to be uncovered well before uncovering IS projects. Life cycle perspective analyses the total material cycle from virgin material to finished material. With respect to industrial symbiosis a life cycle perspective is helpful in assessing symbiotic opportunities. Cascading involves repeated use of resources such as water or energy. It is a common strategy in implementing industrial symbiosis. It reduces impact of resource extraction, reduce using virgin resource and reduce deposition of waste. That is why Cascading is considered as prerequisite of establishing IS projects. Loop closing means recycling or reusing of resources. It is something like cascading but rather than stepwise it is more circular. Tracking material flow is a key element in industrial symbiosis as it tracks flow of material, water, and energy flow. Then inputs and out puts are analyzed to establish inter firm linkage to ensure efficient use of resources.

Table 4: Concerns, expectations and considerations of stakeholders.

\begin{tabular}{|c|c|c|c|}
\hline & Economic & Environmental & Social \\
\hline $\begin{array}{l}\text { Project initiator } \\
\text { partners }\end{array}$ & $\begin{array}{l}\text { Local development. Local appeal. Hub } \\
\text { of skills and competitiveness. Business } \\
\text { longevity. Job preservation and creation. }\end{array}$ & $\begin{array}{l}\text { Environmental impact reduction. Innovation. } \\
\text { Regional influence. Meeting of national } \\
\text { waste management objectives. Improved } \\
\text { environmental quality. }\end{array}$ & $\begin{array}{l}\text { Social responsibility. Local sustainable } \\
\text { development. Transparency. Communication. } \\
\text { Jobs. Influence. Reduced nuisances. }\end{array}$ \\
\hline $\begin{array}{l}\text { Project Management } \\
\text { team/I ndustrial } \\
\text { ecology adviser }\end{array}$ & $\begin{array}{l}\text { New business opportunities. Skilled } \\
\text { workforce training. Innovation. Identification } \\
\text { of complementary businesses. Identification } \\
\text { of R\&D needs. }\end{array}$ & $\begin{array}{l}\text { Optimized resource and waste management. } \\
\text { Calculation of benefit. }\end{array}$ & $\begin{array}{l}\text { Opportunity management. Networking. Ethics. } \\
\text { Confidentiality. Communication between } \\
\text { stakeholders. Information. Formation of skilled } \\
\text { workforce }\end{array}$ \\
\hline $\begin{array}{l}\text { Participating } \\
\text { organizations }\end{array}$ & $\begin{array}{l}\text { Cost reduction. Creation of value. Cost } \\
\text { efficiency. }\end{array}$ & $\begin{array}{l}\text { Regulatory compliance. Management cost } \\
\text { reduction. Increased recyclability of products. } \\
\text { Eco-design. }\end{array}$ & $\begin{array}{l}\text { Retention or creation of commercial } \\
\text { relationships. Creation of local partnership. } \\
\text { Social responsibility. Corporate image. Positive } \\
\text { neighbor relationships. }\end{array}$ \\
\hline Service providers & $\begin{array}{l}\text { Improved service offerings. New clients. } \\
\text { Market sharing and differentiation of } \\
\text { products and services. Cost efficiency. }\end{array}$ & $\begin{array}{l}\text { Supply chain optimization. Formalized } \\
\text { technical specification. }\end{array}$ & $\begin{array}{l}\text { Retention or creation of commercial relationship. } \\
\text { Creation of local partnership. Social } \\
\text { responsibility. Fair competition. }\end{array}$ \\
\hline Technical experts & $\begin{array}{l}\text { Skills and competitiveness hub. Creation } \\
\text { of substitutions and mutualization } \\
\text { opportunities. }\end{array}$ & $\begin{array}{l}\text { R\&D. optimized resource and material } \\
\text { management. Innovation. Eco-design. }\end{array}$ & $\begin{array}{l}\text { Recognition of industrial ecology. Ethics. } \\
\text { Confidentiality. Understanding the mechanisms } \\
\text { of how synergies are carried. }\end{array}$ \\
\hline Community & $\begin{array}{l}\text { Local benefits. Attracting of complementary } \\
\text { businesses to those on site. Regional } \\
\text { planning. }\end{array}$ & $\begin{array}{l}\text { Regulatory compliance. Respect for the } \\
\text { environment. Ecosystem conservation. } \\
\text { Reduced nuisances. }\end{array}$ & $\begin{array}{l}\text { Retention or creation of local jobs. Social } \\
\text { acceptability. Social responsibility. Health } \\
\text { and safety. Quality of life. Hazard control. } \\
\text { Conservation (heritage, landscape, usage etc.) }\end{array}$ \\
\hline
\end{tabular}


Table 5: Environmental benefits achieved by different symbiotic networks.

\begin{tabular}{|c|c|}
\hline Name of IS project & Environmental Benefits \\
\hline \multirow[t]{4}{*}{ Forth Valley (UK) } & $\begin{array}{l}54,000 \text { tpa sewage sludge diverted from } \\
\text { landfill }\end{array}$ \\
\hline & 5,00000 tpa fly-ash diverted from landfill \\
\hline & $\begin{array}{l}42,000 \text { tpa tyres and RLf diverted from } \\
\text { disposal and substituting for } 40,000 \text { tpa coal }\end{array}$ \\
\hline & $\begin{array}{l}\text { 11,000 tpa poultry litter diverted from disposal } \\
\text { and generating } 81 \mathrm{GWh} / \mathrm{yr} \text { renewable power }\end{array}$ \\
\hline Humberside (UK) & $\begin{array}{l}183,000 \text { tpa waste material diverted from } \\
\text { landfill }\end{array}$ \\
\hline \multirow[t]{3}{*}{ Kalundborg (DK) } & $\begin{array}{l}2.1 \text { million tpa potable water replaced by } \\
\text { surface water }\end{array}$ \\
\hline & $\begin{array}{l}\text { Energy savings equivalent to } 30,000 \text { tpa coal } \\
\text { and } 19,000 \text { tpa oil }\end{array}$ \\
\hline & $\begin{array}{l}\text { Some } 280,000 \text { tpa waste diverted from } \\
\text { landfill (fly-ash, scrubber sludge etc) replaced } \\
200,000 \text { tpa gypsum use and } 2,800 \text { tpa } \\
\text { sulphur use }\end{array}$ \\
\hline \multirow{3}{*}{ Moerdijk (NL) } & 85,000 tpa $\mathrm{CO}_{2}$ recovered \\
\hline & 3.4 million tonne/yr steam recovery \\
\hline & $0.5 \mathrm{GL} / \mathrm{yr}$ water reuse \\
\hline Rotterdam (NL) & $6 \mathrm{MW}$ waste heat recovery for district heating \\
\hline Londonderry (USA) & $\begin{array}{l}18 \mathrm{ML} / \text { day reuse of treated waste water as } \\
\text { cooling water }\end{array}$ \\
\hline Sarnia Lambton (CAN) & $\begin{array}{l}\text { Some } 175,000 \text { tpa FGD gypsum diverted from } \\
\text { landfill }\end{array}$ \\
\hline \multirow{3}{*}{ Texas (USA) } & $\begin{array}{l}\text { Energy savings equivalent to } 78,000 \text { tpa coal } \\
\text { use }\end{array}$ \\
\hline & $\begin{array}{l}250,000 \text { tpa waste diverted from landfill } \\
\text { (shredder residue and slags) }\end{array}$ \\
\hline & 18,000 tpa non-ferrus metals recovered \\
\hline \multirow{2}{*}{ Kawasaki (JAP) } & $\begin{array}{l}30,000 \text { tpa waste plastics used as blast } \\
\text { furnace reductant }\end{array}$ \\
\hline & $\begin{array}{l}360 \text { tpa waste plastics gasified for ammonia } \\
\text { production }\end{array}$ \\
\hline \multirow{4}{*}{ Map Ta Phut (Thailand) } & 80 tpa solvent recovered \\
\hline & $\begin{array}{l}11,800 \text { tpa waste oil reused as fuel and/or for } \\
\text { oil paints }\end{array}$ \\
\hline & $\begin{array}{l}640,000 \text { tpa ferrus chloride/hydrochloric acid } \\
\text { recovered }\end{array}$ \\
\hline & $\begin{array}{l}20,000 \text { tpa scale, dust and refractory material } \\
\text { used as cement raw material }\end{array}$ \\
\hline \multirow{3}{*}{ Gladstone (AUS) } & $\begin{array}{l}10,000 \text { tpa bi-product gypsum recovered for } \\
\text { reuse }\end{array}$ \\
\hline & $\begin{array}{l}170,000 \text { tpa } \mathrm{CO}_{2} \text {-eq emission reduction from } \\
\text { one cogeneration plant }\end{array}$ \\
\hline & $\begin{array}{l}9 \mathrm{GL} \text { high grade industrial water recovered } \\
\text { from treated waste water }\end{array}$ \\
\hline
\end{tabular}

Source: (Van Berkel, 2006), *tpa??, FGD??

\section{Benefits of industrial symbiosis}

Industrial symbiosis is a key tool that can be applied in industrial system as we have stated earlier section of this study. It has several benefits that are found from different studies. The principles of industrial ecology and industrial symbiosis predict that turning waste output from one facility into raw material for another facility will lead to environmental benefits caused by reduced intake of virgin material and/or reduced emissions [6]. Centre de transferttechnologique en ecolologieindustrielle [17], suggested that the following concerns, expectations and considerations can be achieved through IS practices (Table 4).

It is very much clear that project initiators are highly concerned to reduce environmental impact and to improve the quality of environment whereas community people emphasizing on ecosystem conservation and nuisances reduction. From economic point of view most of the stakeholders are trying to bring cost efficiency apart from local development and regional planning. Retention or creation of local job, social responsibility towards environmental conservation and attaining sustainability in case of local development are considered as social benefit by stakeholders.

Economic benefit: Economic benefits for the companies emerging from savings in the cost of inputs and the management of waste and opportunities of revenues generated by the higher values of by-products and waste streams [11]. Some of the economic benefit identified by Van Berkel (2006). In Forth Valley (UK) $£ 1.2$ million/yr profit was possible because of reuse of fly-ash. In another IS program, Humberside (UK) economic activity increased $£ 800$ million/yr. Another exemplary IS project was Kalundborg (DK) where Total investment U\$ 75 million, total annual savings U\$ 15 million and accumulated savings U\$ 160 million. In Fairfield (USA) U\$ 62 million investment in redevelopment of industrial facilities (incl. soil remediation) and in Gladstone (AUS) Investment in water reclamation plant a \$29 million $20 \%$ premium price on reclaimed water

Environmental benefit: Environmental benefits usually mean reduction of resources due to the reduction in the overall resource needs of the industrial system, reuse and recycling of waste streams and control of pollution [11]. Van Berkel (2006) distinguished e nvironmental, social and economic benefit of different IS projects. Environmental benefit deciphered by Van Berkel (2006) is given in Table 5.

Maximum environmental benefits derived from Forth Valley and Map Ta Phut projects. It is high time to put concentration on industrial symbiosis network and its widespread circulation across the globe.

Social benefit: Benefits for the community as a source of new employment, securing existing jobs, improving the local ecosystems or the creation of a cleaner and safer environment [11]. There were not much data available to measure Social benefit. Humberside (UK) Saved 87 jobs Potential for 960 direct jobs and 1,440 indirect jobs (Van Berkel, 2006).

Practical implications of industrial symbiosis from different country perspectives:

Industrial symbiosis can be practiced in different sectors of industrial activities. Industrial symbiosis enhances the establishment of eco-industrial network so that more synergy opportunities can be identified [18]. The different sectors which could be brought under the wide schemes of industrial symbiosis are: (a) waste reduction (b) waste reuse and energy generation (c) materials and products 


\begin{tabular}{|c|c|c|}
\hline Country & Participating agency & Location of symbiotic initiatives \\
\hline Australia & Western Australian Water Corporation, University of Canberra & Shenton Sustainability Park, Synergy Park Brisbane \\
\hline China & $\begin{array}{l}\text { SEPA, UNEP, Dalian University of Technology, Tsinghua University of } \\
\text { IE Team, Dalhousie, Indigo, GTZ }\end{array}$ & $\begin{array}{l}\text { Dalian, Yantai, Soo Chow, Tianjin, Guiging, Yixing, Taihu, Shanghai, } \\
\text { Chong Yuan, Guiyang and Jiangsu }\end{array}$ \\
\hline Philippines & UNDP PRIME and EPIC projects, Yale University, USAEP & $\begin{array}{l}\text { Laguna International Industrial Park, Light Industry and Science Park, } \\
\text { Carmelray } \\
\text { Industrial Park, LIMA, Laguna Technopark, Philippine National Oil } \\
\text { Company } \\
\text { Petrochem Industrial Park, Clean City Center project (USAID). }\end{array}$ \\
\hline Indonesia & Kaiserslautern University & Lingkungan (LIK), Tangerang; Semarang; Industri Sona Maris \\
\hline India & $\begin{array}{l}\text { Kaiserslautern University, ICAST, Technology Exchange } \\
\text { Network }\end{array}$ & $\begin{array}{l}\text { Naroda; Tirupur Textile sector; Tamil Nadu tanneries; Calcutta foundries; } \\
\text { Tamil Nadu } \\
\text { paper/sugar; Bangalore water project; Ankleshwar, Nandeseri, Thane- } \\
\text { Belapur. }\end{array}$ \\
\hline Malaysia & USAEP & LHT resources linkage. \\
\hline Japan & UNEP, Tokyo-Osaka-Toyo University, Japanese government & 16 ecotowns (e.g. Kitakyushu, Itabashi), Fujisawa, Toyota city. \\
\hline Korea & NCPC Korea & 15 year three-phase Master EIP Plan launched in 2003 \\
\hline Taiwan & ITRI, Taiwan government & $\begin{array}{l}\text { Tainan Technology and Industrial Park, Changhua Coastal Industrial Park; } \\
\text { CSS II (corporate synergy system II) projects, Hua Lian and Kaohsiung } \\
\text { (2003) }\end{array}$ \\
\hline Vietnam & Amata developer, USAEP, University of Natural Sciences & Amata (environment management), Hanoi Sai Dong II (feasibility study). \\
\hline Thailand & GTZ, IEAT & $\begin{array}{l}\text { Industrial Estate Authority of Thailand plans (Map Ta Phut, northern region, } \\
\text { Amata Nakorn, eastern sea-board, Bang Poo); Samut Prakarn province } \\
\text { CPIE } \\
\text { project (ADB-funded); Bangkok (Panapanaan). }\end{array}$ \\
\hline Singapore & $\begin{array}{l}\text { JTC developer, National University of Singapore } \\
\text { Architecture Department. }\end{array}$ & Jurong Island Industrial Park \\
\hline Sri Lanka & Ministry of Economic and Industrial Development & ADB supported major policy studies in 2002 \\
\hline
\end{tabular}

exchange (d) energy saving etc. A list of practical implications of industrial symbiotic approach for different countries are depicted through Table 6 for better understanding of the scenarios.

\section{Barriers of industrial symbiosis}

Though the industrial symbiosis practices in industries can create benefits in different aspects of economy, environment, and others; successful implementation of it needs to overcome some factors. These factors are the barriers of industrial symbiosis.

Technological barriers: IS projects need some technological changes that may bring about forthcoming challenges to the involved industries. Some industries must have to go for some transitional stages and adaptations. Dynamics of industrial systems have to go through some changes too [11]. Bossilkov et al. [10], also mentioned technological changes as one of the barriers. He also questioned about whether with the existing technologies and industry is well enough to start a by-product synergy. Technological barriers were also identified by Brand \& Bruijn (1999).

Economic barriers: Though IS projects have many befits both environmental and economic, still many industries find it as virtual because industrial set up for all business industries are not equal. Brand \& Bruijn (1999) identified these inequality as economic barrier. For instance, divergences in production cycle varies from industries to industries so it is very much questionable whether by products are feed able to other industries with in the given time period [11]. Another important thing is geographic proximity and it may hinder by product exchange because of unavailability of low cost transport system [10].

Informational barriers: In time of uncovering stage, industries suffocate to establish self-organized industrial symbiosis because they usually lack information about other companies' by-products and waste flow. Chertow [6] found this problem at uncovering stage. Similar result was also found by Fichtner et al. and Aparisi $[9,11]$.

Absence of trust among organization (Organizational barrier): Industrial symbiosis programs need several industries to work together and run under several symbiotic exchange. That is why Bossilkov et al. [10], questioned about if the industries are comfortable with working together. Competition among similar industries, lack of environmental consciousness among companies, resistance to change are some reasons why industries are themselves to be considered as barriers [11]. Fichtner et al. [9], identified that Enterprise level barriers are created due to presence of communication related barriers. Intercompany level barriers can also be created when there exits co-operational and inter-connectional barriers.

Regulatory barriers: Laws and regulation can be both good and bad for uncovering industrial symbiosis. Regulatory instruments can hinder the exchange of by products or the creation of alliance [11]. Government may be a barrier to synergies through regulatory instruments (e.g. through legislative process). Bossilkov et al. [10], also questioned about whether rules and regulation are encouraging or discouraging industries to work together. Chertow [6], found 
importance of government's role in formulating and implementing regulation to start a symbiotic relation. Fichtner et al. [9], addressed it as political barrier.

Risk and uncertainty: IS exchanges may generate uncertainties regarding the outcome, performance or cost benefit ratio [11]. Again increased inter-dependency among the industries can increase vulnerability and thus risk of investment increases. And thus vulnerability to context changes [10]. He also questioned whether transportation of a "waste" and use of a by-product lead to increased liability.

\section{Policy instruments for IS}

Industrial symbiosis ensures optimization of resources; as a result a "win- win" situation evolves. Though it has some barriers like trust building and emotional barriers, informational barriers, regulatory barriers, economic barriers, technological barriers, risk and uncertainty, cultural barriers, most of these barriers can be overcome by an interactive policy framework [11].

Policy is a set of actions taken by government body which includes public interest and government strategy. Policy of industrial symbiosis should find out pathways of how principles of industrial symbiosis are incorporated into national policy and what should be their characteristics of national policy and management strategies. Four concepts of Policy Science (policy implementation, policy diffusion, policy transfer, and policy translation) are often used to explain the dissemination phenomena. Aparisi [11] discussed the components of policy of Industrial Symbiosis under three main levels of analysis. The first level deals with institutional framework that influences the political decision-making process, knowledge, values and principles. The second level and third level respectively refers to the regulations and promotion of IS projects. Policy implementation discuss on executing the objectives of a policy usually in the top-down hierarchy direction. Policy transfer and policy diffusion are both used to explain ways of how knowledge about policies used across time or space in the development of policies elsewhere, while the latter one emphasizes on the convergence of policy. Policy approaches needs to disseminate at all levels of stakeholders. It commonly involves: (1) setting goals, objectives, (2) developing instruments of regulatory, economic and informational/ voluntary nature [13]. They also analyzed policy development at three levels: (1) Supra- national level, (2) national policies and (3) Sub national policies. Coordinating organizations at supra national levels arrange conventions or programs to mitigate transnational challenges. Beside these, national governments works on social, environmental and social context and sometimes incorporate with supra national level. Lastly sub-national policy interventions are formed at region, state or municipality but aligned same with national and supra national policy context [13] (Figure 1).

Chertow [6], proposed three potential policy ideas of industrial symbiosis at uncovering stage. These are to:

Bring to light kernels of co-operative activity that are still hidden: Business managers know about their byproducts, but lack of access to information about their neighboring industry hinders the potential role of material exchange. Mapping flows of heavy industries can uncover many kernels of exchange and it should be widely dispersed and should include smaller and less industrial companies.

Assist the kernels that are taking shape: Where a kernel exists and involves two or three firms to facilitate an industrial symbiosis, they also need assistance to form a distinct shape. Further query should be continued to discover new trading ideas.

Provide incentives to catalyze new kernels by identifying "Precursors to symbiosis": Provide incentives to catalyze new kernels by identifying "precursors to symbiosis": In industrial system there are some common environmentally related activities those can be seen as precursors to symbiosis. Simply precursors to symbiosis can be defined as a resource exchange with the public goods component but it will involve only one or two firms or other organizations. Examples of such precursors to symbiosis are the projects that share resources involving: (1) Landfill gas (2) cogeneration (3) waste water reuse.

Eilering \& Vermeulen [19], discussed (five) policy instruments for IS projects which may differ in terms of enforceability. Legislation was the first and foremost policy instrument considered by them. Other elements are financial incentives, park management agreement, input and exchange of knowledge and experience and promotion and acquisition of new or existing industrial parks are also mentioned as important policy instruments. The identification of good anchor

Table 7: Suggested policy framework under different themes.

\begin{tabular}{|l|l|}
\hline Themes & Including policy instruments \\
\hline $\begin{array}{l}\text { An integrated framework to support } \\
\text { the greening of industries }\end{array}$ & $\begin{array}{l}\text { Development of national strategies, institutional integration, policy implementation, and the potential role of transition } \\
\text { management in green industries. }\end{array}$ \\
\hline Creating an enabling environment & $\begin{array}{l}\text { Government influence to support the greening of industries measures include the removal of harmful subsidies green } \\
\text { procurement, financial support structure harnessing the benefits of globalization, trade agreement resource co-efficient } \\
\text { infrastructures, and developing the skill necessary to support the greening of a industries. }\end{array}$ \\
\hline $\begin{array}{l}\text { Supporting an industry led } \\
\text { initiatives }\end{array}$ & $\begin{array}{l}\text { Government supported industry led initiative to promote efficiencies and environmental improvement. Eco level and } \\
\text { certification, life-cycle analysis, green supply chain, extended producer responsibility, raising awareness, and capacity } \\
\text { development. }\end{array}$ \\
\hline $\begin{array}{l}\text { Harnessing environmental } \\
\text { technologies }\end{array}$ & $\begin{array}{l}\text { Role of government in facilitating the creation and diffusion of environmental technologies, emphasizing the importance } \\
\text { of technical capacity, building a science base financing technology development, technology diffusion, science networks, } \\
\text { collaboration, and infrastructure. }\end{array}$ \\
\hline promote the greening of industries & Influence of government policy instruments to promote sustainable production and sound environmental management. \\
\hline Source: (UNIDO, 2011) [22]. & \\
\hline
\end{tabular}




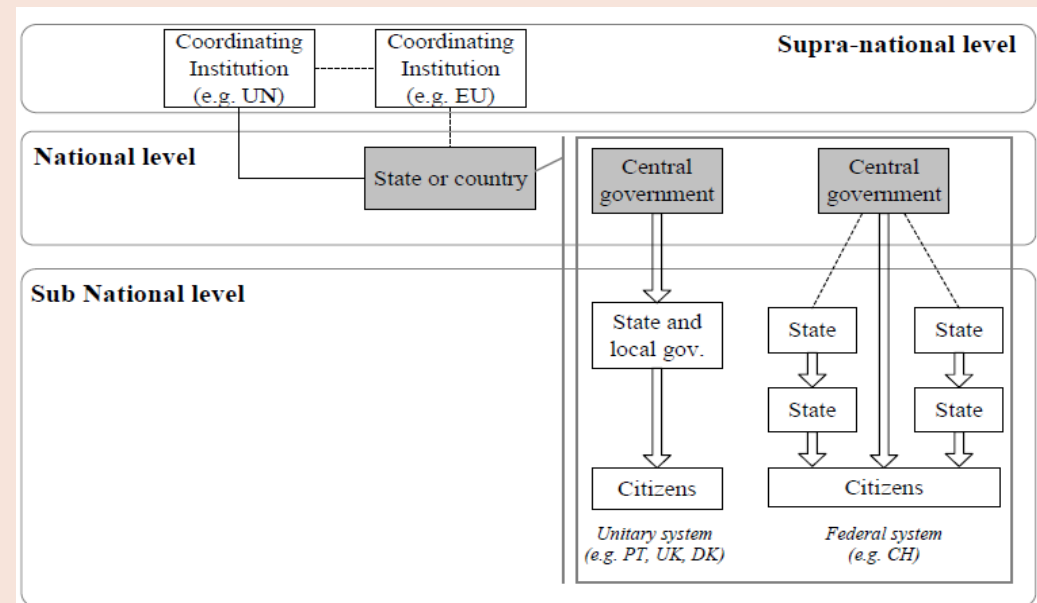

Figure 1: Policy formulation network for IS network( adapted from Costa et at., 2010) [23].

tenants is also a successful policy instruments for promoting the development of industrial symbiosis. It would allow for the creation of policy targeted at the correct industries and companies, allowing for the creation of appropriate policy, without the challenges of being applied universally, which has the potential to have significant environmental impact [1]. Other than this, industrial firms play a leading role in environmental management and policy. They mainly focus on (i) optimization of voluntary approaches that can be effective in bringing about environmental improvement, and (ii) reliance on industrial firms as the locus of technological expertise, which in turn, is seen as crucial to strategies emphasizing design for environment [20]. Besides, Environment laws and regulations can be introduced to encourage industry to adopt environmental technology and form symbiotic linkages. Industrial symbiosis became more economically feasible under the law. Environment taxes on certain raw resources foster the development of synergies to consume fewer raw materials [14]. Technology, business case and license to operate or legislation, are three success factors for symbiotic synergies. A sustainable policy framework can foster these elements to make a compatible synergy [10]. In a report of United Nations Industrial development Organization provided a policy framework were viewed under five themes (Table 7).

\section{Conclusion}

Concept of industrial symbiosis is borrowed from biological concept where two or more industries form a cluster to share their by-products for their own betterment. It is now considered as one of the sustainable instruments that will sure to reign future industrial mechanism. Industrial symbiosis brings about sustainability by initiating the circular flow systems within the industrial sector rather age old linear flow system. This technology is also known as cleaner technology where it aims to achieve resource efficiency by reducing usage of virgin material. Reduction of usage of virgin material also reduces waste generation. Empirical research has learnt a lot about the phenomenon of business entities from research of last 25 years. The focus of the article was only to accumulate determinants, approaches, benefits and barriers, and essential policy instruments suggested and documented in empirical research. Two approaches of emergence of industrial symbiosis can be easily distinguished. Some industries of proximate distance come forward to share their by-product within them and this approach is known as spontaneous approach while second one is rather planned. But spontaneous and planned symbiotic networks had to go through some difficulties like technological barrier, informational barrier, lacking of trust, economic barriers at their uncovering stage. Future research is needed to find out solutions of the existing barrier. Empirical research suggested that both regulatory body and the industrial entities are responsible to search possible pathways that will hopefully minimize barriers. Again some of already established symbiotic networks are economically and environmentally successful. Factors beyond these success story needs to be replicated and barriers that hindered the growth needs to be resolved or exempted. Policy formulation is one of the possible solutions and policy maker needs to work simultaneously at regional, national and supra international level with some standard procedure. One of such example is NISP which facilitated industrial symbiosis pilot programme in the United Kingdom in 2004 through which extra landfill tax was imposed to make the industries recycle their waste from landfill to produce raw material. Finally, authors hope that this article will help public and private actors to undertake appropriate decision in respective field and provide many opportunities to the potential industries opt for symbiotic network.

\section{References}

1. Gingrich C (2012) Industrial symbiosis: Current understandings and needed ecology and economics influences. Ontario center for Engineering and Publication 44-46.

2. Granovetter M (1985) Economic action and social structure: The problem of Embeddedness. American Journal of Sociology 91: 481-510.

3. Desrochers P, Leppälä S (2010) Industrial symbiosis: old wine in recycled bottles? Some perspective from the history of economic and geographical thought. International Regional Science Review 33: 338-361.

4. Chertow MR (2000) Industrial symbiosis: literature and taxonomy. Annual review of energy and the environment 25: 313-337. 
5. Frosch RA, Gallopoulos NE (1989) Strategies for Manufacturing: Waste from one industrial process can serve as the raw materials for another, thereby reducing the impact of industry on the environment. Scientific American 3: 144-152.

6. Chertow MR (2007) Uncovering industrial symbiosis. Journal of Industrial Ecology 11: 11-30

7. Lombardi DR, Laybourn $P$ (2012) Redefining Industrial Symbiosis: Crossing Academic-Practitioner Boundaries. Journal of Industrial Ecology, 16: 28-37.

8. Massard G, Jacquat O, Zürcher D (2014) International survey on ecoinnovation parks. In Workshop on eco-innovation parks 20: 12.

9. Fichtner W, Tietze-Stöckinger I, Frank M, Rentz O (2005) Barriers of interorganisational environmental management: two case studies on industrial symbiosis. Progress in Industrial Ecology, an International Journal 2: 73-88.

10. Bossilkov A, Van Berkel R, Corder G (2005) Regional synergies for sustainable resource processing: a status report.

11. Aparisi D, T A (2010). Social aspects of industrial symbiosis networks. UCL (University College London).

12. Paquin RL, Howard Grenville J (2012) The evolution of facilitated industrial symbiosis. Journal of industrial Ecology 16: 83-93.

13. Costa I, Ferrão P (2010) A case study of industrial symbiosis development using a middle-out approach. Journal of Cleaner Production 18: 984-992.

14. Teh BT, Ho CS, Matsuoka Y, Chau LW, Gomi K (2014) Determinant factors of industrial symbiosis: greening Pasir Gudang industrial park. IOP Conference Series: Earth and Environmental Science 18: 012162.
15. Boons F, Spekkink W, Mouzakitis Y (2011) The dynamics of industrial symbiosis: a proposal for a conceptual framework based upon a comprehensive literature review. Journal of Cleaner Production 19: 905-911.

16. Van Berkel R (2007) Regional Resource Synergies for Sustainable Development in Heavy Industrial Areas: an overview of opportunities and experiences. Curtin University of Technology, Perth (WA).

17. Centre de transferttechnologique en ecolologieindustrielle (2013) Creating an Industrial Symbiosis 44

18. Geng Y, Tsuyoshi F, Chen X (2010) Evaluation of innovative municipal solid waste management through urban symbiosis: a case study of Kawasaki. Journal of Cleaner Production 18: 993-1000.

19. Eilering JA, Vermeulen WJ (2004) Eco-industrial parks: toward industrial symbiosis and utility sharing in practice. Progress in Industrial Ecology. an International Journal 1: 245-270.

20. Thomas V, Theis T, Lifset R, Grasso D, Kim B, et al. (2004) Industrial ecology: Policy potential and research needs. Environmental Engineering Science 20: $1-9$.

21. Chiu ASF, Yong G (2004) On the industrial ecology potential in Asian developing countries. Journal of Cleaner Production 12: 1037-1045.

22. UNIDO (2011) UNIDO Green Industry: Policies for supporting Green Industry. United Nations Industrial Development Organization.

23. Costa I, Massard G, Agarwal A (2010) Waste management policies for industrial symbiosis development: case studies in European countries. Journal of Cleaner Production 18: 815-822.

Copyright: (c) 2016 Rahman MF, et al. This is an open-access article distributed under the terms of the Creative Commons Attribution License, which permits unrestricted use, distribution, and reproduction in any medium, provided the original author and source are credited. 